\title{
Application of life cycle assessment to sheep production systems: investigating co-production of wool and meat using case studies from major global producers
}

\author{
Stephen G. Wiedemann • Stewart F. Ledgard • Beverley K. Henry • \\ Ming-Jia Yan $\cdot$ Ningtao Mao $\cdot$ Stephen J. Russell
}

Received: 11 June 2014 / Accepted: 5 January 2015 /Published online: 28 January 2015

(C) The Author(s) 2015. This article is published with open access at Springerlink.com

\begin{abstract}
Purpose Methodology of co-product handling is a critical determinant of calculated resource use and environmental emissions per kilogram $(\mathrm{kg})$ product but has not been examined in detail for different sheep production systems. This paper investigates alternative approaches for handling coproduction of wool and live weight (LW, for meat) from dual purpose sheep systems to the farm-gate.

Methods Seven methods were applied; three biophysical allocation (BA) methods based on protein requirements and partitioning of digested protein, protein mass allocation (PMA), economic allocation (EA) and two system expansion (SE) methods. Effects on greenhouse gas (GHG) emissions, fossil energy demand and land occupation (classified according to suitability for arable use) were assessed using four contrasting case study (CS) farm systems. A UK upland farm (CS 1) and a New Zealand hill farm (CS 2) were selected to represent systems focused on lamb and coarse-textured wool for interior textiles. Two Australian Merino sheep farms (CS 3, CS 4) were selected to represent systems focused on medium to superfine garment wool, and lamb.
\end{abstract}

Responsible editor: Niels Jungbluth

S. G. Wiedemann $(\bowtie) \cdot$ M.-J. Yan

FSA Consulting, 11 Clifford Street, Toowoomba, QLD, Australia

e-mail: stephen.wiedemann@fsaconsulting.net

S. F. Ledgard

AgResearch Ruakura Research Centre, Private Bag 3123, Hamilton, New Zealand

\section{B. K. Henry}

Institute for Future Environments, Queensland University of

Technology, 2 George St, Brisbane, Australia

N. Mao $\cdot$ S. J. Russell

Centre for Technical Textiles, School of Design, University of Leeds, Leeds, UK
Results and discussion Total GHG emissions per kilogram total products (i.e. wool $+\mathrm{LW}$ ) were similar across CS farms. However, results were highly sensitive to the method of coproduct handling. GHG emissions based on BA of wool protein to wool resulted in $10-12 \mathrm{~kg} \mathrm{CO}_{2}$-e/ $\mathrm{kg}$ wool (across all CS farms), whereas it increased to $24-38 \mathrm{~kg} \mathrm{CO}_{2}$-e/kg wool when BA included a proportion of sheep maintenance requirements. Results for allocation\% generated using EA varied widely from $4 \%$ (CS 1) to $52 \%$ (CS 4). SE using beef as a substitution for sheep meat gave the lowest, and often negative, GHG emissions from wool production. Different methods were found to re-order the impacts across the four case studies in some instances. A similar overall pattern was observed for the effects of co-product handling method on other impact categories for three of the four farms.

Conclusions BA based on protein partitioning between sheep wool and LW is recommended for attributional studies with the PMA method being an easily applied proxy for the more detailed BA methods. Sensitivity analysis using SE is recommended to understand the implications of system change. Sensitivity analysis using SE is recommended to investigate implications of choosing alternative products or systems, and to evaluate system change strategies in which case consequential modelling is appropriate. To avoid risks of burden shifting when allocation methods are applied, results should be presented for both wool and LW.

Keywords Allocation - Carbon footprint - GHG · Land use · LCA

\section{Introduction}

Sheep are an important part of the global agricultural economy due to their multi-functional role in the production of meat, wool, milk and co-products (e.g. skins, tallow, blood and 
renderable products), as well as for their wider range of cultural and ecological benefits (Zygoyiannis 2006). Sheep also contribute to the substantial environmental impacts of livestock production systems, which occupy over onequarter of the world's land surface area and contribute significant quantities of greenhouse gas (GHG) emissions (Steinfeld et al. 2006). The impacts of the production and consumption of agricultural products are best assessed by accounting for resource use and environmental emissions throughout the full life cycle of a product, and life cycle assessment (LCA) is an important methodology for this (e.g. ISO 2006). However, this is a relatively new area of research and while some LCA studies have been published for livestock products, almost all have been restricted to GHG emissions assessment and carbon footprinting of products. There is a dearth of research on other resource use or environmental impact categories. Additionally, while research on the use of LCA for dairy (Flysjö et al. 2011; Thomassen et al. 2009; van der Werf et al. 2009) and beef production (Lieffering et al. 2010; Nguyen et al. 2012; Peters et al. 2010; Wiedemann et al. 2015a; Williams et al. 2006) has been reported for several major production regions of the world, there are fewer published LCAs on sheep and most of these have focussed on lamb production. Lamb LCA studies cover production in a range of regions, notably the Mediterranean (RipollBosch et al. 2013), New Zealand (NZ) (Gac et al. 2012; Ledgard et al. 2011), the United Kingdom (UK) (EdwardsJones et al. 2009; Williams et al. 2006) and Australia (Peters et al. 2010; Wiedemann et al. 2015b). Only two published studies have specifically investigated the LCA of wool, with both examining meat and wool production from single-casestudy farms in Australia (Brock et al. 2013; Eady et al. 2012).

A feature common to many sheep farms that adds a degree of complexity to LCA studies is the co-production of meat, wool and milk (FAOSTAT 2014). While for some sheep flocks, particularly in Asia, Africa and parts of Europe, sheep milk is economically and nutritionally important, it is relatively unimportant for most other temperate regions where meat and wool are the main products. Depending on the breed of sheep, the relative proportion and quality of wool and meat may vary, as may the emphasis of the production system towards either product. In some cases, sheep systems exclusively produce meat from shedding sheep such as the Dorper breed, while other meat sheep produce low value wool as a by-product of meat production. In many cases, the system is 'dual purpose' producing both wool and meat for economic returns. In these systems, differences in the breed of sheep and production objectives result in variation in the relative quantity of meat production and in the quality and end-use of wool.

Co-production must be addressed in LCA studies, and the results can be sensitive to the assumptions made on apportioning environmental impact between products, and hence can vary significantly depending on the methods used (Ayer et al. 2007; Reap et al. 2008). As interest in the environmental impacts of livestock increases (Gerber et al. 2013), results for sheep meat and wool production are needed. The aims of this research are to: (1) evaluate several alternative methods for handling the co-production of meat and wool from sheep production systems; (2) quantify the impacts of these allocation methods across multiple impact categories; and (3) discuss the implications of allocation methods for benchmarking studies and scenario modelling for improved practices. A series of case studies were drawn from the major sheepproducing regions of Australia, NZ and UK, which together account for approximately $35 \%$ of global clean wool production (FAOSTAT 2014). The case studies were selected to illustrate the impact of alternative methodologies for handling co-products in systems diverging in relative production emphasis on wool or meat The study did not aim to provide comparative benchmarking results for the countries represented.

\section{Methods}

\subsection{Goal and scope}

The case study system boundaries included all supply chain processes associated with the primary production of wool and sheep meat to the farm-gate. Two functional units (FU) were used either independently or together, depending on the main output of the system and the method applied for handling coproduction. Where allocation methods were used, results for meat are presented for live weight (LW) per 'one kilogram of LW at the farm gate' and for wool, results are presented per 'one kilogram of greasy wool at the farm gate'.

\subsection{Case study descriptions}

Four case studies were used, based on survey data collected over the years 2009 to 2012, from farms representative of major agro-ecological zones, with different sheep production systems and breeds. These systems differed in emphasis on LW and wool production, the level of productivity and regional location as summarised in Table 1. All case studies were pasture grazing systems where the majority of feed inputs are sourced from permanent pastures year-round, with the exception of the UK system where sheep are housed in winter.

\subsubsection{Case study 1 (CS 1)}

Sheep production in UK is focused primarily on meat production and wool is generally considered as a by-product of limited value that rarely returns more than $4 \%$ of average farm-gate revenue (Chris Lloyd, pers. comm.). Most wool is coarse-textured and is used for carpets, apparel and household 
Table 1 Case study farm inventory of flock characteristics and production, resource use and emissions

\begin{tabular}{|c|c|c|c|c|}
\hline Production system characteristics & CS 1 & $\mathrm{CS} 2$ & CS 3 & CS 4 \\
\hline Country & United Kingdom & New Zealand & Australia & Australia \\
\hline Sheep breed & Lleyn and Cheviot & Romney dominant & Merino, Meat Merino & Merino \\
\hline \multicolumn{5}{|l|}{ Wool and meat characteristics } \\
\hline Diameter $(\mu \mathrm{m})$ & c. 30 & 32 & 21 & 17 \\
\hline Typical use & Interior textiles & Interior textiles & Outer garment & 'near skin' garment \\
\hline Typical lamb carcase weight (kg) & $<20 \mathrm{~kg}$ dressed & $<20 \mathrm{~kg}$ dressed & $20-24 \mathrm{~kg}$ dressed & $<18 \mathrm{~kg}$ dressed \\
\hline \multicolumn{5}{|l|}{ Production details } \\
\hline Stocking rate $\left(\mathrm{DSE}^{\mathrm{a}} / \mathrm{ha}\right)$ & 14.7 & 15.1 & 0.4 & 7.4 \\
\hline Ewe standard reference weight (kg) & 68 & 60 & 60 & 45 \\
\hline Lambing \% (at marking) & 145 & 127 & 98.3 & 86.4 \\
\hline Annual wool clip (total kg greasy) & 3410 & 8236 & 10,619 & 6,219 \\
\hline Annual sheep sales (total kg LW) & 56,812 & 47,858 & 50,100 & 36,125 \\
\hline Total farm-gate production (greasy wool + LW) (kg) & 60,222 & 56,094 & 60,719 & 42,344 \\
\hline Whole flock wool production per breeding ewe (kg greasy) & 3.4 & 8.2 & 10.6 & 6.2 \\
\hline \multicolumn{5}{|l|}{ Resources and emissions } \\
\hline Arable land occupation (cultivated) - ha & 3.6 & 3.1 & 0.1 & 9.2 \\
\hline Arable land occupation (pasture) — ha & 3.6 & 24.6 & 0.0 & 16.2 \\
\hline Non-arable land occupation)_- ha & 135 & 193 & 9,305 & 332 \\
\hline Total fossil fuel energy demand)-MJ oil-e ${ }^{b}$ & 457,668 & 310,734 & 290,376 & 259,475 \\
\hline $\mathrm{GHG})-\mathrm{kg} \mathrm{CO}-\mathrm{e}^{\mathrm{b}}$ & 581,796 & 477,384 & 525,089 & 442,889 \\
\hline Methane)_ $\%$ of $\mathrm{GHG}$ & 72 & 77 & 88 & 84 \\
\hline Nitrous oxide) — $\%$ of $\mathrm{GHG}$ & 21 & 18 & 9 & 10 \\
\hline Carbon dioxide) — $\%$ of $\mathrm{GHG}$ & 7 & 5 & 3 & 6 \\
\hline
\end{tabular}

All datasets were scaled to a standardised flock size of 1000 ewes joined, inclusive of rams, replacements and lambs

${ }^{a} D S E$ dry sheep equivalent, equivalent to an annual feed consumption rate of $400 \mathrm{~kg}$ DMI

${ }^{\mathrm{b}}$ Equivalents

products. A typical case study upland farm (hill country) was selected from the EBLEX 2011 survey farms (EBLEX 2012). This farm is located in an upland region characterised as a less favoured area (LFA) due to its varied topography and relatively high rainfall of at least $1200 \mathrm{~mm} /$ year. The LFA is significant for the UK because approximately $50 \%$ of the national flock is found in the uplands LFA. This sheep-only farm system was characterised by high productivity in terms of weaning percentages and growth rates, from large bodied sheep with low wool production (Table 1). Sheep are housed over winter for 1 month when they are fed pasture silage, hay and by-products from horticulture such as surplus potatoes. Concentrates are fed to ewes during the 6 weeks prior to lambing and to lambs to finish them before sale for slaughter at an average of 6 months after birth.

\subsubsection{Case study 2 (CS 2)}

NZ sheep production is based on dual-purpose sheep, with most revenue from meat but with wool contributing about 20 $25 \%$ of the average farm-gate revenue. The majority (c. $98 \%$ ) of the wool is coarse-textured and is primarily used for interior textiles. Most NZ sheep are on hill country and the case study selected is based on the average hill farm from the Beef + LambNZ Class 4 farms (Beef+LambNZ 2013), which produce $27 \%$ of all NZ lamb and $32 \%$ of total strong wool production (Beef+LambNZ 2013 economic service survey data). Farm data represent the average of 151 farms surveyed by Beef+LambNZ across hill country in the North Island of NZ (average rainfall $1420 \mathrm{~mm} /$ year). The farm also contained cattle (representing $48 \%$ of total stocking rate or feed intake) and a combination of system separation (where possible) and biophysical allocation (BA) based on relative feed intake were used to separate out the sheep component of the farm system for this study. Sheep in this system are characterised by moderately high body weights, fecundity and wool production (Table 1).

\subsubsection{Case studies 3 and 4 (CS 3, CS 4)}

The majority of Australia's sheep flock is based on the Merino breed, which produces high to very high quality wool for garment manufacture. Modern Australian Merino sheep 
production systems are typically managed to optimise production of both wool and meat, as this is the most profitable production scenario. Case study three was based on farm data from three fine-medium wool Merino production systems from the semi-arid pastoral zone $(250-350 \mathrm{~mm}$ average annual rainfall) in South Australia (unpublished data). Sheep in this system are characterised by high body weights and high yields of wool and LW (Table 1). Case study four was based on farm data from three superfine wool production systems in the northern tablelands of New South Wales (unpublished data), which is a higher rainfall zone $(700-800 \mathrm{~mm}$ average annual rainfall) known for producing superfine to ultra-fine Merino wool. This strain of Merino sheep has lower body weights and lower yields of wool and LW than sheep in case study 3 (Table 1).

\subsection{Inventory and impact assessment}

The total GHG impact assessment applied Global Warming Potentials (GWPs) based on the IPCC Fourth Assessment Report (Solomon et al. 2007). Inventory categories assessed were cumulative fossil energy demand based on the method outlined by Frischknecht et al. (2007) and land occupation.

\subsubsection{Modelling feed intake and greenhouse gas emissions from livestock systems}

Feed and animal production data were used as a basis for modelling feed intake and GHG emissions from livestock systems. Feed intake for CS 1 and CS 2 was modelled using equations from the Australian Feeding Standards (Freer et al. 1997) as applied in the NZ national GHG inventory (MfE 2010). Feed intake for CS 3 and CS 4 were modelled based on AFRC (1990) equations as applied by the Australian national GHG inventory (DCCEE 2012). The NZ feed intake model was applied to CS 1 as the UK apply a less detailed tier one method in their national accounts which was of insufficient detail to account for specific aspects of the CS 1 flock such as live weight, wool weight and differences in lamb age and weight at sale.

Critical assumptions and references for calculation of livestock GHG emissions are provided in Table 2 and GHG emissions for each supply chain are shown in Table 1 . Emissions from other processes and inputs such as from fertiliser and fossil fuel use throughout the cradle-to-farmgate were modelled from inventory data.

\subsubsection{Land occupation}

Within LCA, land occupation has commonly been reported as an impact category (de Vries and de Boer 2010), though where land use is simply reported as a unit area of land for a given period of time (i.e. $\mathrm{m}^{2} /$ year) this more accurately reflects an inventory value than an impact assessment value (Koellner et al. 2013). As noted by Koellner et al. (2013), land use inventories should identify the current use of the land. Globally, sheep production systems utilise a wide variety of land types, and where land occupation is used as a measure of the efficiency of resource use for food or fibre production, it is fundamentally important to classify land in terms of potential alternative uses. In the present study, we classify land occupation in three categories at the inventory level that reflect the quality of the land for use in other agricultural systems and a measure of the disturbance of that land. These three broad land types are: arable land used for cultivation, arable land used for pasture (potentially suitable for cropping) and non-arable land used for grazing (unsuitable for arable crops). Inventory data are presented in Table 1 and results are presented for the land currently used for cultivation only.

\subsubsection{Fossil fuel energy demand}

Fossil fuel energy demand was associated with both direct energy use on farm (from fuel, oil and electricity), and energy use in the manufacture and transport of goods and services used by the farms. Modelling of energy demand was based on the inventory of purchased goods, services and transport distances obtained from farm records or surveys (see Table 1).

\subsection{Handling co-production}

Sheep production systems commonly produce both wool and meat, with different proportions and quality of the wool product. Sheep production systems also commonly produce two meat products (lamb and mutton) of different eating quality. Multiple products present a challenge for assessing the inputs for and impacts of the product in question. The options for handling co-production according to ISO 14044 (ISO 2006) in order of preference are:

Methods to avoid allocation:

- Clear subdivision of the system; or

- System expansion (SE) (expanding the product system to include the additional functions related to the co-products to avoid allocation).

Allocation:

- Allocation on the basis of physical or biological relationship; or

- Allocation on some other basis, most commonly economic (market) value.

Sheep are often produced in systems that include other agricultural production either from other livestock species (such as beef cattle) or crops (i.e. cereal grains). This issue is not addressed specifically by this paper, though in the case 
Table 2 Major GHG emission sources and methods

\begin{tabular}{|c|c|c|c|}
\hline Emission source & Unit & $\begin{array}{l}\text { Sheep systems) - UK \& NZ } \\
\text { Key parameters/model } \\
\text { (Reference) }\end{array}$ & $\begin{array}{l}\text { Sheep systems)-Australia } \\
\text { Key parameters/model } \\
\text { (reference) }\end{array}$ \\
\hline \multirow[t]{2}{*}{ Enteric methane } & $\begin{array}{l}\text { Methane }\left(\mathrm{CH}_{4}\right) \text { emitted by adult } \\
\text { sheep }\end{array}$ & $0.0209 \mathrm{~kg} \mathrm{CH} / \mathrm{kg}$ (DMI, MfE 2010) & $\begin{array}{l}\mathrm{CH}_{4}=\mathrm{DMI}(\mathrm{kg} / \mathrm{hd} \text { day }) \times 0.0188+0.00158 \\
(0.0204 \mathrm{~kg} \mathrm{CH} / \mathrm{kg} \mathrm{DMI})(\mathrm{DCCEE} \\
\text { 2012, citing Howden et al. 1994) }\end{array}$ \\
\hline & $\begin{array}{l}\text { Methane }\left(\mathrm{CH}_{4}\right) \text { emitted by young } \\
\text { sheep }(<1 \text { year })\end{array}$ & $0.0168 \mathrm{~kg} \mathrm{CH}_{4} / \mathrm{kg}$ DMI (MfE 2010) & $\begin{array}{c}\mathrm{M}=\mathrm{DMI}(\mathrm{kg} / \mathrm{hd} \text { day }) \times 0.0188+0.00158 \\
\quad(0.0204 \mathrm{~kg} \mathrm{CH} / \mathrm{kg} \text { DMI })(\text { DCCEE 2012, } \\
\text { based on Howden and Munro 1994) }\end{array}$ \\
\hline Excreta methane & $\begin{array}{l}\text { Kilograms } \mathrm{CH}_{4} \text { emitted per kilogram } \\
\text { faecal dry matter (DM) }\end{array}$ & $\begin{array}{l}6.9 \times 10^{-4} \mathrm{~kg} \mathrm{CH}_{4} / \mathrm{kg} \text { faecal DM } \\
\quad(\mathrm{MfE} 2010)\end{array}$ & $\begin{array}{l}5.4 \times 10^{-5} \mathrm{~kg} \mathrm{CH}_{4} / \mathrm{kg} \text { faecal DM } \\
(\text { DCCEE 2012) }\end{array}$ \\
\hline \multirow[t]{2}{*}{ Excreta nitrous oxide } & $\begin{array}{l}\text { Kilograms of } \mathrm{N}_{2} \mathrm{O}-\mathrm{N} \text { emitted per } \\
\text { kilogram of } \mathrm{N} \text { due to urine deposited } \\
\text { during grazing (EF3) }\end{array}$ & $\begin{array}{l}\text { Urinary } \mathrm{N}-0.01 \mathrm{~kg} \mathrm{~N} \mathrm{~N}_{2} \mathrm{O}-\mathrm{N} / \mathrm{kg} \\
\mathrm{N} \text { in urine }(\mathrm{MfE} 2010)\end{array}$ & $\begin{array}{l}\text { Urinary } \mathrm{N}-0.004 \mathrm{~kg} \mathrm{~N} \mathrm{~N}_{2} \mathrm{O}-\mathrm{N} / \mathrm{kg} \mathrm{N} \text { in urine } \\
\text { (DCCEE 2012) }\end{array}$ \\
\hline & $\begin{array}{l}\text { Kilograms of } \mathrm{N}_{2} \mathrm{O}-\mathrm{N} \text { emitted per } \\
\text { kilogram of } \mathrm{N} \text { due to dung deposited } \\
\text { during grazing (EF3) }\end{array}$ & $\begin{array}{l}\text { Faecal } \mathrm{N}-0.0025 \mathrm{~kg} \mathrm{~N}_{2} \mathrm{O}-\mathrm{N} / \mathrm{kg} \\
\mathrm{N} \text { in faeces }(\mathrm{MfE} 2010)\end{array}$ & $\begin{array}{l}\text { Faecal } \mathrm{N}-0.005 \mathrm{~kg} \mathrm{~N} \mathrm{~N}_{2} \mathrm{O}-\mathrm{N} / \mathrm{kg} \mathrm{N} \text { in faeces } \\
\quad \text { (DCCEE 2012) }\end{array}$ \\
\hline $\begin{array}{l}\text { Nitrous oxide from } \\
\text { stored manure }\end{array}$ & $\begin{array}{l}\text { Kilograms of } \mathrm{N}_{2} \mathrm{O}-\mathrm{N} \text { emitted per } \\
\text { kilogram of } \mathrm{N} \text { due to manure storage }\end{array}$ & $\begin{array}{l}\text { Manure } \mathrm{N}-0.02 \mathrm{~kg} \mathrm{~N}{ }_{2} \mathrm{O}-\mathrm{N} / \mathrm{kg} \\
\mathrm{N} \text { in stored manure (IPCC 2006) }\end{array}$ & n.a \\
\hline Excreta ammonia & $\begin{array}{l}\text { Kilograms of } \mathrm{NH}_{3}-\mathrm{N} \text { emitted per kilogram } \\
\text { of } \mathrm{N} \text { excreted (FRACGASM) }\end{array}$ & $\begin{array}{l}0.1 \mathrm{~kg} \mathrm{NH}_{3}-\mathrm{N} / \mathrm{kg} \mathrm{N} \text { of excreted } \\
\quad(\mathrm{MfE} 2010)\end{array}$ & $\begin{array}{l}0.2 \mathrm{~kg} \mathrm{NH}_{3}-\mathrm{N} / \mathrm{kg} \mathrm{N} \text { of excreted } \\
\text { (DCCEE 2012) }\end{array}$ \\
\hline $\begin{array}{l}\text { Ammonia from stored } \\
\text { manure }\end{array}$ & $\begin{array}{l}\text { Kilograms of } \mathrm{NH}_{3}-\mathrm{N} \text { emitted per kilogram } \\
\text { of } \mathrm{N} \text { in manure (FRACGASM) }\end{array}$ & $\begin{array}{l}0.12 \mathrm{~kg} \mathrm{NH}_{3}-\mathrm{N} / \mathrm{kg} \mathrm{N} \text { in stored } \\
\text { manure (IPCC 2006) }\end{array}$ & n.a \\
\hline $\begin{array}{l}\text { Indirect nitrous oxide } \\
\text { from ammonia } \\
\text { losses }\end{array}$ & $\begin{array}{l}\text { Kilograms of } \mathrm{N}_{2} \mathrm{O}-\mathrm{N} \text { emitted per kilogram } \\
\text { of } \mathrm{N} \text { due to atmospheric deposition } \\
\text { of } \mathrm{NH}_{3} \text { (EF4) }\end{array}$ & $\begin{array}{l}0.01 \mathrm{~kg} \mathrm{~N}_{2} \mathrm{O}-\mathrm{N} / \mathrm{kg} \mathrm{NH}_{3}-\mathrm{N} \\
\text { volatilised } \\
\text { (IPCC 2006) }\end{array}$ & $\begin{array}{l}0.01 \mathrm{~kg} \mathrm{~N}_{2} \mathrm{O}-\mathrm{N} / \mathrm{kg} \mathrm{NH}_{3}-\mathrm{N} \text { volatilised } \\
\quad \text { (DCCEE 2012) }\end{array}$ \\
\hline Excreta nitrate & $\begin{array}{l}\text { Kilograms of } \mathrm{NO}_{3}-\mathrm{N} \text { emitted per kilogram } \\
\text { of } \mathrm{N} \text { excreted or } \mathrm{N} \text { fertiliser applied } \\
\text { (FRACLEACH) }\end{array}$ & $\begin{array}{l}0.07 \mathrm{~kg} \mathrm{NO}-\mathrm{N} / \mathrm{kg} \mathrm{N} \text { of excreted } \\
\text { (Thomas et al. 2005) }\end{array}$ & $\begin{array}{l}\text { 'Drylands' with the ratio of } \\
\text { evapotranspiration to precipitation is } \\
\text { outside the range where leaching is } \\
\text { assumed to occur (i.e. Et/P } \\
<0.8 \text { or Et } / P>1 \text { ) (DCCEE 2012) }\end{array}$ \\
\hline $\begin{array}{l}\text { Indirect nitrous oxide } \\
\text { from nitrate losses }\end{array}$ & $\begin{array}{l}\text { Kilograms of } \mathrm{N}_{2} \mathrm{O}-\mathrm{N} \text { emitted per kilogram } \\
\text { of } \mathrm{N} \text { due to leaching and runoff of } \\
\mathrm{NO}_{3} \text { (EF5) }\end{array}$ & $\begin{array}{l}0.0075 \mathrm{~kg} \mathrm{~N} \mathrm{~N}_{2} \mathrm{O}-\mathrm{N} / \mathrm{kg} \mathrm{NO}_{3}-\mathrm{N} \\
\quad \text { leached } \\
\text { (IPCC 2006) }\end{array}$ & n.a (see above) \\
\hline
\end{tabular}

studies reported here, impacts were divided between subsystems and treated separately. This was done by dividing specific inputs and outputs and attributing these to the subsystem that used or generated them. Inputs and outputs associated with general farm processes were divided using the proportion of land resource used by each sub-system. For mixed sheep and cattle grazing systems, the inputs and emissions were first subdivided where possible and then the remainder were allocated on a biophysical basis according to the relative amount of feed eaten by each animal species.

Handling co-production of wool and meat from sheep is more complex, because the system cannot be divided. In the case studies investigated, wool and meat were jointly produced from sheep flocks, though the value and significance of each product varied greatly. While meat was produced from both lambs and cull for age (CFA) breeding animals (mutton), these were not differentiated because both meat products were considered to be functionally comparable (i.e. provision of a high quality protein food source for human consumption). A comparison of seven possible methods for handling co- production of wool and LW was included, these being: BA based on partitioning of digested protein (three methods) or protein mass; economic allocation (EA); and SE (two methods). These are described in the following paragraphs.

\subsubsection{Methods for conducting biophysical allocation}

The BA approach was based on the work of Cronje (2012). Wool production is mainly determined by requirements for protein, rather than energy requirements which is the key determinant for milk production (CSIRO 2007). Cronje (2012) suggested using the proportion of Digestible Protein Leaving the Stomach (DPLS) as the biophysical basis for dividing impacts between wool and LW. The DPLS requirements were determined using CSIRO (2007) methods for each flock, and total requirements for maintenance (from endogenous urinary and faecal protein), wool and LW growth, including conceptus growth, were calculated. While this method provides base-level data to inform allocation decisions, subjective decisions are still required to allocate impacts 
between wool and meat. We investigated three alternative allocation scenarios based on these data: (i) allocation to wool and sheep meat based on the fraction of protein required for wool or meat divided by total utilised digestible protein from the whole flock (BA 1); (ii) allocation based on division of the maintenance requirements for the breeding flock between wool and meat according to the wool to sheep meat ratio (as in (i)) together with all maintenance requirements for slaughter lambs directly attributed to meat and all direct requirements for growth attributed to meat (BA 2); and (iii) allocation of all flock maintenance requirements and requirements for live weight production to the meat product, and allocation of direct wool protein requirements to the wool product (BA 3).

\subsubsection{Methods for conducting protein mass and economic allocation}

Allocation was performed using protein mass and economic value, based on farm-gate protein and value for greasy wool and LW (averaged over a minimum of 2 years). The protein content of greasy wool was estimated from the protein content of clean wool on a dry matter basis (i.e. $100 \%$ ) adjusted for the dry matter content of clean wool $(84 \%)$ and ratio of clean wool to greasy wool. The protein content of live weight was assumed to be $18 \%$ based on Sanson et al. (1993) using a fixed assumption applied to all case studies in the absence of specific data regarding sheep condition scores. The allocation assumptions are provided in Table 3.

\subsubsection{Methods for conducting system expansion}

Considering the focus of this paper on wool, the SE methods accounted for avoided meat production via substitution. SE by

Table 3 Assumptions used in calculating factors for protein mass and economic allocation

\begin{tabular}{|c|c|c|c|c|c|}
\hline & & CS 1 & CS 2 & CS 3 & $\mathrm{CS} 4$ \\
\hline \multicolumn{6}{|l|}{ Protein mass factors } \\
\hline $\begin{array}{l}\text { Protein content of } \\
\text { greasy wool }\end{array}$ & & $70 \%$ & $66.6 \%$ & $57.1 \%$ & $57.1 \%$ \\
\hline $\begin{array}{l}\text { Protein content of } \\
\text { LW }\end{array}$ & & $18.0 \%$ & $18.0 \%$ & $18.0 \%$ & $18.0 \%$ \\
\hline \multicolumn{6}{|l|}{ Economic factors } \\
\hline Wool value $^{\mathrm{b}}$ & $\begin{array}{r}£ \text { or } \$ / \mathrm{kg} \\
\text { greasy }\end{array}$ & 1.09 & 2.76 & 6.80 & 9.80 \\
\hline $\begin{array}{l}\text { LW value } \text { e }^{\mathrm{b}} \text { (average } \\
\text { of all sales over } \\
\geq 2 \text { year period) }\end{array}$ & $\begin{array}{c}£ \text { or } \$ / \mathrm{kg} \\
\mathrm{LW}\end{array}$ & 1.56 & 1.98 & 1.63 & 1.57 \\
\hline
\end{tabular}

${ }^{\text {a }}$ Protein content of greasy wool varies because of extraneous materials that are present on the fibre such as vegetable matter, dirt, suint and grease

${ }^{\mathrm{b}}$ Values refer to currency for individual countries (in March 2014, relativity is approximately 1.8:0.9:1, for UK£, NZ\$, AU\$) substitution (the avoided burden method) is more commonly applied in consequential LCA and application for attributional studies has been questioned by some (Brander and Wylie 2011) but supported by others in some situations (Weidema 2000). As the method is a preferred option in the international standards for LCA (ISO 14044), application is justified as a comparison method. This approach has been applied in attributional studies, typically using average data for the substituted product (Finnveden et al. 2009). In this study, two constraints were applied when determining the avoided system: (i) the product must be a suitable replacement in the market; and (ii) the production system must be a suitable replacement taking into account the biophysical (land) resources available to the current sheep system. This latter criterion was included to minimise indirect effects relating to transfers of land resources from one industry to another and possible land use change emissions as a result of the substitution process. Using these two criteria, the avoided product system was assumed to be beef cattle or sheep using different sheep breeds where the focus is strongly oriented towards meat rather than wool. While a number of alternative meat and non-meat products may be possible substitutes for sheep meat in the market, these could not be produced on the majority of land used for the sheep production systems studied, which is non-cultivatable. Alternative grain protein products rely on cultivated land directly, while in the case of pork or poultry cultivated land is required for feed production.

Case study 1 For the UK case study, this analysis was based on the avoided product system being beef cattle that were produced on the same farm. Data for the carbon footprint (CF) of beef produced in this farm class category in the UK (based on ten beef farm system analyses by EBLEX 2012) was $13.4 \mathrm{~kg} \mathrm{CO} \mathrm{CO}_{2}$-e/kg LW. Equivalence factors were applied to adjust for the lower carcase yield from sheep compared to beef cattle. Dressing percentages for sheep were assumed to be $45 \%$, compared to $51 \%$ for beef cattle (EBLEX 2013).

Case study 2 For the NZ case study, it was assumed that the avoided product was beef produced on the same farm class as for sheep. In practice, beef is also produced on these farm systems and this scenario assumed that the farm only carried sheep and not cattle. Data for the resource use and environmental emissions for beef had been calculated as part of this project and in a related NZ beef study (Lieffering et al. 2010). The average $\mathrm{CF}$ of beef at the farm-gate was $12.16 \mathrm{~kg} \mathrm{CO}_{2}$-e/ $\mathrm{kg}$ LW for Class 4 farm beef. The corresponding value for fossil fuel energy demand was $7.07 \mathrm{MJ} / \mathrm{kg}$ beef LW, and land occupation values were $0.37,2.92$ and $23.0 \mathrm{~m}^{2} / \mathrm{kg} \mathrm{LW}$ beef for cultivated land, arable pasture and non-arable land, respectively. Equivalence factors were applied to adjust for the lower carcase yield from sheep compared to beef cattle. Dressing 
percentages for sheep were assumed to be $45 \%$, compared to $51.8 \%$ for beef cattle (e.g. Beef + LambNZ 2013).

Case studies 3 and 4 Two alternative meat production systems were identified; beef cattle and sheep production based on an alternative sheep breed. Two different alternative sheep systems were proposed, both with a strong emphasis on lamb production and either minor or no emphasis on wool production. In CS 3, the alternative sheep system was a composite crossbreeding system based on Border Leicester crossbred ewes and Poll Dorset rams. This system produced low value wool suitable for interior textiles, requiring a second substitution product, for which nylon was selected. In CS 4, the alternative system was based on Dorper breed sheep which shed their fleece naturally each year, producing no saleable wool. The average CF of the alternative sheep meat was $9.5 \mathrm{~kg}$ $\mathrm{CO}_{2}$-e $/ \mathrm{kg} \mathrm{LW} \mathrm{(CS} \mathrm{3)} \mathrm{and} 10.7 \mathrm{~kg} \mathrm{CO}$-e/kg LW (CS 4). Corresponding values for fossil fuel energy demand were 5.1 and $-6.1 \mathrm{MJ} / \mathrm{kg} \mathrm{LW}$ for CS 3 and CS 4, respectively. Land occupation values were $0.01,0.0$ and $1081.5 \mathrm{~m}^{2} / \mathrm{kg} \mathrm{LW}$ for CS 3 and 1.6, 3.1 and $62.4 \mathrm{~m}^{2} / \mathrm{kg} \mathrm{LW}$ for CS 4 , for cultivated land, arable pasture and non-arable land, respectively. The average $\mathrm{CF}$ of beef production was $13.5 \mathrm{~kg} \mathrm{CO}$-e $/ \mathrm{kg} \mathrm{LW}(\mathrm{CS} \mathrm{3}$ ) and $11.9 \mathrm{~kg} \mathrm{CO}$-e $/ \mathrm{kg} \mathrm{LW}$ (CS 4) and fossil fuel energy demand was $6.5 \mathrm{MJ} / \mathrm{kg} \mathrm{LW}$ for both CS 3 and CS 4. Land occupation values for cattle were $0.01,0.0$ and $1312.4 \mathrm{~m}^{2} / \mathrm{kg} \mathrm{LW}$ for CS 3 and $1.5,2.8$ and $56.4 \mathrm{~m}^{2} / \mathrm{kg} \mathrm{LW}$ for CS 4 , for cultivated land, arable pasture and non-arable land, respectively. Equivalence factors were applied to adjust for the lower carcase yield from Merino sheep compared to meat breed sheep and cattle. Dressing percentages from Merino sheep were assumed to be $44 \%$, compared to $46 \%$ for meat breed sheep and $52 \%$ for cattle (MLA 2003).

\section{Results}

3.1 Partitioning of DPLS based on animal function and allocation methods

Partitioning of DPLS requirements for the different sheep functions showed that wool constituted only $7 \%$ of the total for CS 1 but was up to $22 \%$ of the total for CS 3 (Table 4), coinciding with relative differences in flock wool production per ewe (Table 2). In contrast, there was little difference in the proportion of DPLS for growth (conceptus + LW gain), at 19$24 \%$ of the total. Total maintenance requirements dominated DPLS at $54-69 \%$ of total requirements.

The three methods of calculating BA between wool and meat showed differences according to how the maintenance component of DPLS was allocated. When maintenance was
Table 4 Partitioning of DPLS for sheep flocks in the case study regions (based on Cronje 2012)

\begin{tabular}{|c|c|c|c|c|}
\hline & $\begin{array}{l}\text { CS } 1 \\
(\%)\end{array}$ & $\begin{array}{l}\text { CS } 2 \\
(\%)\end{array}$ & $\begin{array}{l}\text { CS } 3 \\
(\%)\end{array}$ & $\begin{array}{l}\text { CS } 4 \\
(\%)\end{array}$ \\
\hline $\begin{array}{l}\text { Maintenance-flock (excluding } \\
\text { lambs sold for slaughter) }\end{array}$ & 54.7 & 54.1 & 42.5 & 55.0 \\
\hline $\begin{array}{l}\text { Maintenance-lambs sold for } \\
\text { slaughter }\end{array}$ & 14.3 & $6.0^{\mathrm{a}}$ & 12.8 & 11.3 \\
\hline Wool & 7.0 & 17.3 & 22.2 & 15.1 \\
\hline Conceptus & 2.6 & 2.7 & 3.5 & 2.9 \\
\hline LW gain & 21.4 & 19.9 & 19.0 & 15.7 \\
\hline Total & 100.0 & 100.0 & 100.0 & 100.0 \\
\hline Utilised Digestible Protein $^{\mathrm{b}}$ & 31.0 & 39.9 & 44.7 & 33.7 \\
\hline
\end{tabular}

${ }^{\mathrm{a}}$ Lower value associated with early sale for processing of a proportion of lambs at weaning

${ }^{\mathrm{b}}$ Utilised digestible protein is the sum of all protein required directly for production of wool and LW

allocated according to the relative requirements for wool and growth (BA 1) it resulted in values for allocation to wool of $22-50 \%$ to wool (for CS 1 to CS 3, respectively). The corresponding range in allocation values for wool where all maintenance was allocated to meat (BA 3) was 7 to $22 \%$. Allocation by protein mass in wool and LW resulted in 19 to $40 \%$ allocation to wool (for CS 1 and 3, respectively). The largest variation in calculated percentage allocation to wool between farms was in EA, which ranged from 4 to $52 \%$ (for CS 1 and 4, respectively).

\subsection{Impact of choice of method for handling co-products} on greenhouse gas emissions

GHG emissions were 9.7, 8.5, 8.6 and $10.5 \mathrm{~kg} \mathrm{CO}_{2}$-e for CS $1-4$, respectively, when presented on an unallocated, mass basis (i.e. per kilogram total wool and LW product), showing a variation of $<25 \%$. Differences in GHG emissions were due to underlying differences in the production systems and emission sources between the countries, which was not the focus of the study and results should not be interpreted as representative of each country. However, when methods for handling coproduction were applied, GHG results differed substantially between methods (Fig. 1). Emissions per kilogram wool differed by two- to three-fold (depending on case study) by applying BA 1 and BA 3 methods, reflecting the difference in percent allocation in Table 5. The ranking of case study farms was similar across BA 1 to BA 3, although CS 1 and 4 were highest for BA 1 whereas there was little difference for BA 3. The greater mass of LW relative to wool made results more consistent across these different allocation methods for LW (Fig. 2) than for wool (Fig. 1), with the difference between the two most divergent BA methods (BA 1 and BA 3) being $53-69 \%$ for wool but only $17-39 \%$ for sheep meat. Results 


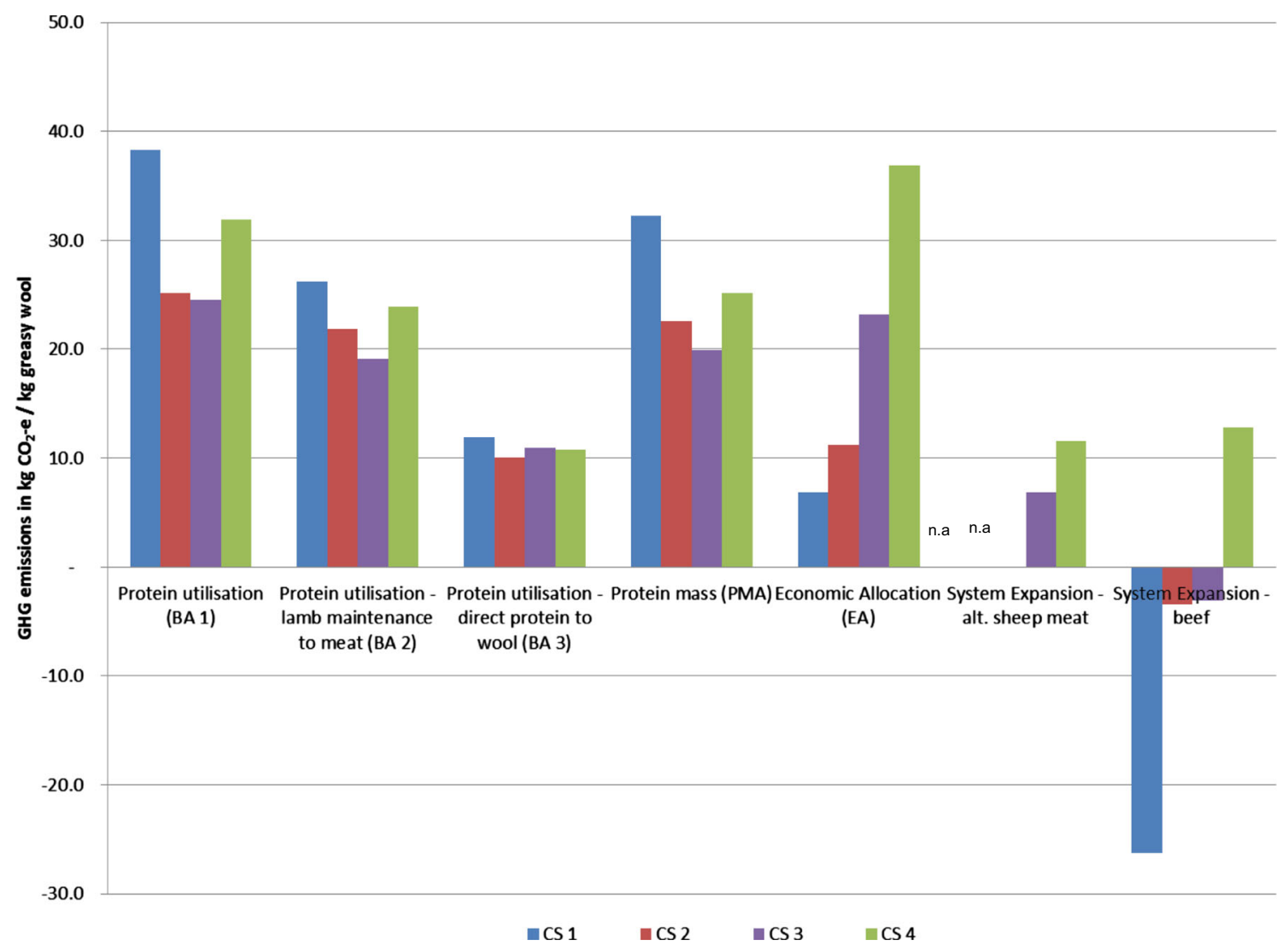

Fig. 1 GHG emissions from greasy wool production across four case studies assessed with seven alternative methods for handling co-production of wool and LW. n.a. not applicable because no meat-specific sheep breeds were identified for the case study

Table 5 Effects of different allocation methods on relative allocation between wool and meat

\begin{tabular}{lllll}
\hline Allocation method & $\begin{array}{l}\text { CS 1 } \\
(\%)\end{array}$ & $\begin{array}{l}\text { CS 2 } \\
(\%)\end{array}$ & $\begin{array}{l}\text { CS 3 } \\
(\%)\end{array}$ & $\begin{array}{l}\text { CS 4 } \\
(\%)\end{array}$ \\
\hline
\end{tabular}

BA based on the proportion of utilised protein for wool and meat Allocation factor for wool)-BA $1 \quad 22 \quad 43 \quad 50 \quad 45$

Allocation factor for meat)-BA $1 \quad \begin{array}{llll}78 & 57 & 50 & 55\end{array}$

BA based on allocation to meat of the maintenance requirements for lamb, LW gain and a proportion of flock maintenance

$$
\begin{array}{lllll}
\text { Allocation factor for wool)-BA 2 } & 15 & 38 & 39 & 34 \\
\text { Allocation factor for meat)-BA 2 } & 85 & 62 & 61 & 66
\end{array}
$$

BA based on all maintenance requirements to sheep meat and direct protein requirements to wool only

$\begin{array}{llllll}\text { Allocation factor for wool)-BA } 3 & 7 & 17 & 22 & 15 \\ \text { Allocation factor for meat)-BA 3 } & 93 & 83 & 78 & 85\end{array}$

Allocation based on protein mass

$\begin{array}{lllll}\text { Allocation factor for wool } & 19 & 39 & 40 & 35\end{array}$

$\begin{array}{lllll}\text { Allocation factor for meat } & 81 & 61 & 60 & 65\end{array}$

EA

\begin{tabular}{lllll} 
Allocation factor for wool & 4 & 19 & 47 & 52 \\
Allocation factor for meat & 96 & 81 & 53 & 48 \\
\hline
\end{tabular}

from the PMA method approximated those for the BA 2 method across all case studies.

Results produced using EA did not correspond to the underlying biophysical characteristics for wool (Fig. 1). Notably, results from CS 1 were lowest using the EA method and highest using all of the biophysical methods, while results from CS 4 were highest using EA and intermediate using the biophysical methods. Differences in the economic value of products resulted in large differences between EA values across the case studies, ranging from 4 to $52 \%$ of impacts being allocated to wool for the most divergent case studies, CS 1 and CS 4, respectively (Table 5). Differences were less pronounced between the biophysical methods and EA for live weight (Fig. 2).

The two SE methods resulted in lower GHG emissions for wool than the allocation methods for three of the four case studies because of the high livestock emissions from the substitution system. Values ranged from negative (CS 1) to moderate (CS 4) in comparison to those for the allocation methods when beef was the substitution product. The range in SE values across the case studies using beef as a substitution product was the result of two main differences: the emissions intensity of the substitution product and the mass of LW produced. The divergent results from CS 1 and CS 4 were related to higher 


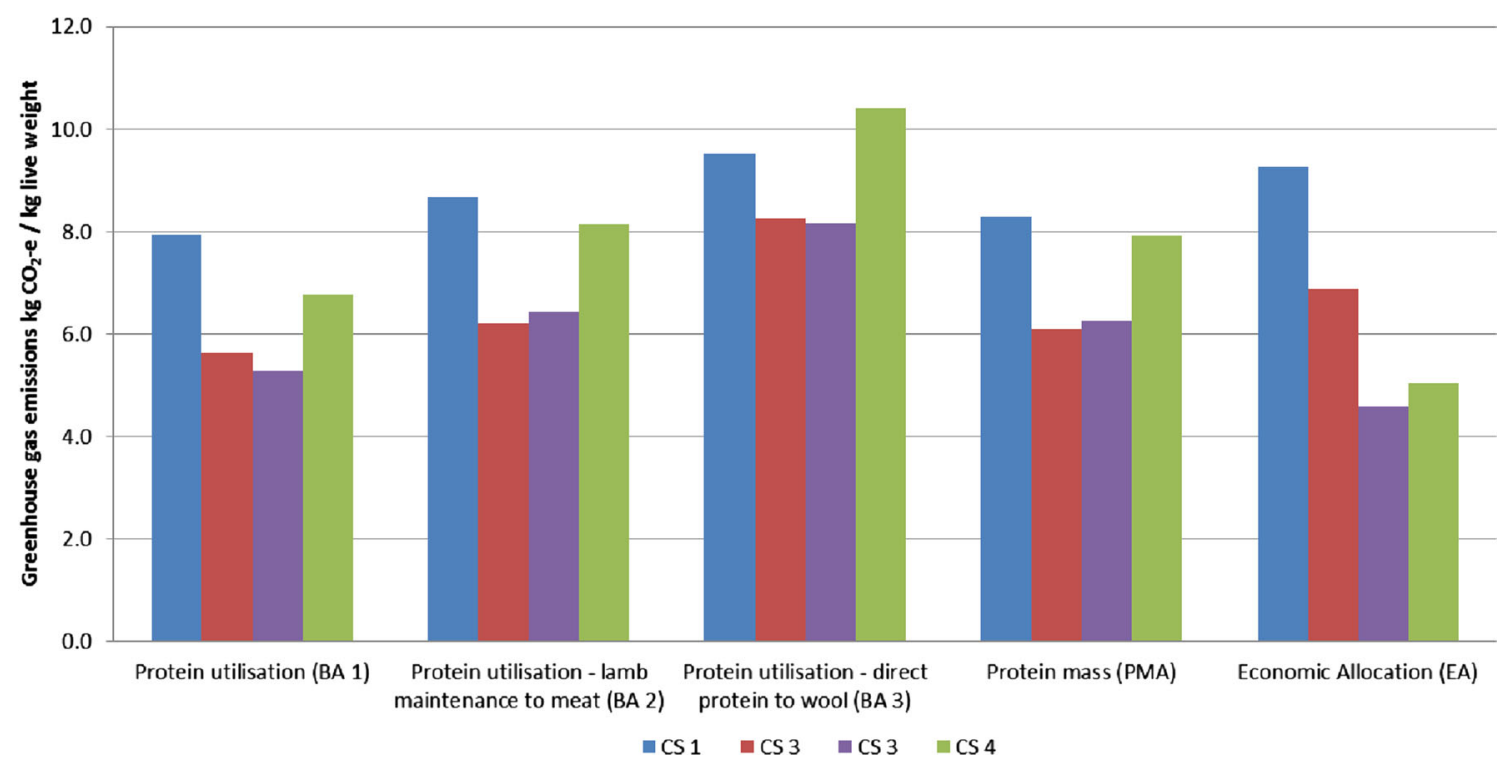

Fig. 2 GHG emissions from LW production across four case studies assessed with five alternative methods for handling co-production of wool and LW

emissions intensity of the beef product for CS 1 combined with higher LW productivity for CS 1 compared to CS 4.

\subsection{Fossil fuel energy}

The same range between the allocation methods shown in the GHG results was also observed in the fossil fuel results (Fig. 3). Results from the SE scenarios followed a broadly similar trend where beef was the alternative product. In the two scenarios where an alternative sheep system was modelled (CS 3 and CS 4), results were similar to beef when substituting with shedding sheep (no allocation to wool-CS 3) but differed when using an alternative sheep system that also produced wool, requiring a second substitution process to account for avoided strong wool production. This product was substituted for nylon, which accounted for the elevated energy use.

\subsection{Land occupation}

Comparison of methods for handling co-production confirmed the same broad trends for land occupation as observed for GHGs. Estimates of land occupation per kilogram wool using BA1 were two- to four-fold higher than estimates using $\mathrm{BA} 3$, with estimates for BA2 being intermediate and similar

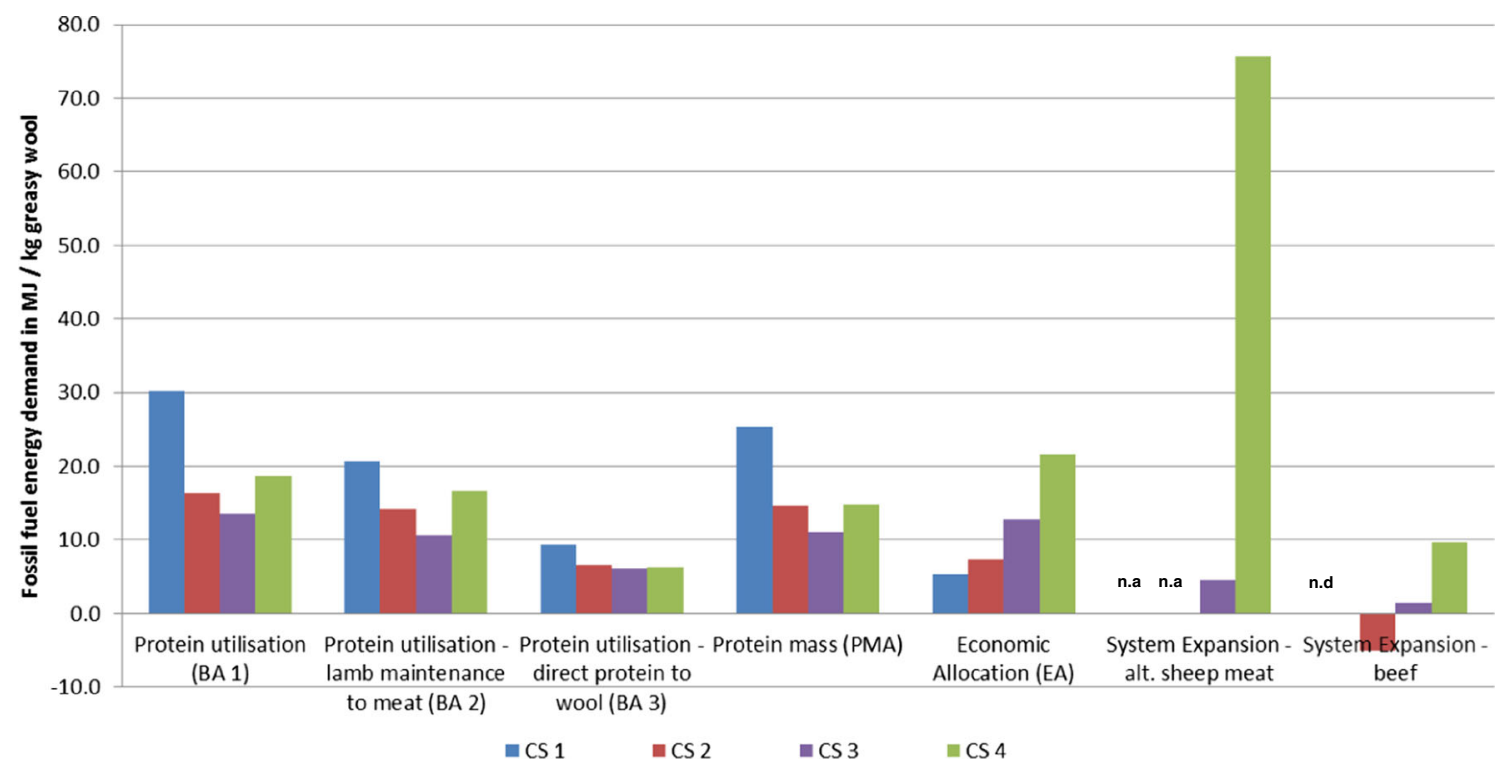

Fig. 3 Fossil fuel energy demand for greasy wool production across four case studies assessed with seven alternative methods for handling co-production of wool and LW. n.a. not applicable because no meat-specific sheep breeds were identified for the case study. $n . d$. not determined due to non-availability of data 
to those using PMA. Use of EA resulted in wide variation between CS farms. However, compared to the other impact categories, application of SE resulted in smaller differences in cultivated land attributed to wool compared to the allocation methods. For CS 4, application of SE based on an alternative sheep meat system produced the highest estimate of all methods.

The land occupation inventory revealed that sheep systems utilised very little land potentially suitable for cropping, representing $0-12 \%$ of the total land occupation (Table 1). The inventory of land occupation showed large differences in total land area per kilogram of wool and meat (data not shown) with the highest land occupation associated with CS 3, a farm located in a semi-arid region of Australia where stocking rate was low (Table 1). The area of cultivated land occupation was low across all case studies, ranging from close to zero for CS 3 to $13.8 \mathrm{~m}^{2} / \mathrm{kg}$ wool in CS 4 (SE) (Table 6). Using allocation methods only, cultivated land occupation ranged from 0.007 for CS 3 to $1.97 \mathrm{~m}^{2} / \mathrm{kg} \mathrm{LW}$ for CS 4 (Table 7).

\section{Discussion}

This paper is the first to examine in detail the effects of a range of methods for co-product handling across diverse sheep systems. In particular, it examines in detail the complexity of BA methods based on protein utilisation, and contrasts this with EA methods and SE. This study was confined to the cradle-to-farm-gate stage of the life cycle of sheep products and further research is needed to handle co-products associated with wool and meat processing. Nevertheless, research in

Table 6 Cultivated land occupation for wool production assessed with seven alternative methods for handling co-production of wool and LW

\begin{tabular}{|c|c|c|c|c|}
\hline & CS 1 & $\mathrm{CS} 2$ & CS 3 & $\mathrm{CS} 4$ \\
\hline & \multicolumn{4}{|c|}{ Cultivated land $\left(\mathrm{m}^{2}\right.$ year $/ \mathrm{kg}$ greasy wool) } \\
\hline BA 1 & 2.40 & 0.87 & 0.04 & 7.31 \\
\hline BA 2 & 1.64 & 0.76 & 0.03 & 5.68 \\
\hline BA 3 & 0.74 & 0.35 & 0.01 & 3.27 \\
\hline PMA & 1.87 & 0.78 & 0.03 & 5.92 \\
\hline EA & 0.43 & 0.39 & 0.05 & 6.91 \\
\hline SE - alt. sheep meat & $\mathrm{n} \cdot \mathrm{a}^{\mathrm{a}}$ & n.a ${ }^{a}$ & 0.04 & 13.81 \\
\hline SE - beef & n.d ${ }^{\mathrm{b}}$ & 0.16 & 0.03 & 7.31 \\
\hline
\end{tabular}

All flocks standardised to 1000 ewes joined, inclusive of rams, replacement breeders and lambs

${ }^{a}$ n.a. not applicable because no meat-specific sheep breeds were identified for the case study (CS)

${ }^{\mathrm{b}}$ n.d. not determined due to non-availability of data
Table 7 Cultivated land occupation for live weight (LW) production assessed with five alternative methods for handling co-production of wool and LW

\begin{tabular}{lllll}
\hline & CS 1 & CS 2 & CS 3 & CS 4 \\
\hline \multicolumn{5}{c}{ Cultivated land $\left(\mathrm{m}^{2}\right.$ year/kg LW) } \\
BA 1 & 0.497 & 0.195 & 0.010 & \\
BA 2 & 0.543 & 0.215 & 0.012 & 1.276 \\
BA 3 & 0.597 & 0.285 & 0.016 & 1.557 \\
PMA & 0.520 & 0.211 & 0.012 & 1.972 \\
EA & 0.58 & 0.237 & 0.007 & 1.147 \\
\hline
\end{tabular}

All flocks standardised to 1000 ewes joined, inclusive of rams, replacement breeders and lambs

$\mathrm{NZ}$ on wool processed into fabrics, garments or carpets used overseas (NZ Merino unpublished, Basset-Mens et al. 2007) and on meat consumed in distant overseas markets (Ledgard et al. 2011) indicated that for GHGs the cradle-to-farm-gate is the dominant contributor to life cycle emissions, constituting about $80 \%$ or more of total emissions, and therefore warrants most research emphasis on methodology. This paper also went beyond examining impacts for GHGs only by including two additional inventory categories of importance to extensive sheep production systems in order to consider any broader implications or trade-offs associated with allocation choice.

With the advancement of global benchmarking activities by the Food and Agriculture Organisation of the United Nations (FAO) which include assessment of impacts from sheep (Opio et al. 2013), a robust method for handling coproduction is required. In making these decisions, the requirements for benchmarking and impact assessment for two separate commodity groups (food and textiles) must be taken into account. This would be advanced if studies chose to present and discuss results for both products rather than using allocation as a means of simplifying the system to focus on one product such as meat (e.g. Ledgard et al. 2011; Opio et al. 2013; Peters et al. 2010; Williams et al. 2006) or wool only (Eady et al. 2012).

The choice of methods for handling co-production for wool must be done with careful consideration of the goal and scope of the study and the intended end-use of the results. Sheep meat and wool LCA research to date has focussed on quantification of impacts of existing product systems and hot-spot analysis. Many of the published studies represent the first of their type (e.g. Ledgard et al. 2011; Peters et al. 2010; Williams et al. 2006) for their respective countries. In practice, allocation methods are often favoured for attributional studies oriented towards benchmarking and hot-spot analysis. The harmonisation of allocation methods is advantageous to avoid inaccurate comparisons; hence, the development of guidelines that provide more stringent directives regarding allocation (i.e. BSI 2011; LEAP 2014). However, there are several plausible 
alternative methods that produce different results for meat and wool.

\subsection{Biophysical allocation}

The biophysical methods presented here provide a new basis for performing allocation between wool and meat. As both wool and meat are proteinaceous products and wool production is largely determined by protein requirements (CSIRO 2007), this provides a logical basis for determining allocation. However, subjective decisions still remain with respect to the allocation of maintenance requirements for the animal to either meat or wool, and the approach used was found to have a significant influence on the results. Biologically, the maintenance requirements for ruminant animals are the largest component of either protein or energy requirements. Hence, the subjective choice about how to manage this is both inevitable and highly significant. We evaluated this choice by allocating maintenance in three ways but acknowledge other possibilities also exist. Eady et al. (2012) applied a quite different BA method in a sheep system where the primary product was considered to be wool. These authors attributed all impacts associated with maintenance of the sheep flock to the wool product and only attributed direct additional requirements associated with meat production to LW. This bears some similarity to BA approaches developed for dairy cattle (e.g. Dolle et al. 2011) and is similar to the BA 3 method presented here, though the emphasis on wool and LW is reversed.

The BA 1 and BA 2 methods are based on apportioning protein requirements for maintenance between wool and meat, with BA 1 being similar to that recommended by IDF (2010) for allocating between milk and meat, i.e. according to the ratio of requirements for each product. BA 2 was similar except that the maintenance requirement for lambs sold for meat was fully allocated to meat. The impact of small differences in allocation methods was highlighted by comparison of results across the case studies with different methods applied. We found that even between similar biophysical methods (BA 1 and BA 2), results could be re-ordered across the CS farm systems if the methods were not harmonised, as evidenced by comparison of CS 1 (using BA 2) with CS 4 (using BA 1), This highlights the importance of harmonisation of BA methods and explicit explanation of methods in research papers to ensure sound conclusions are drawn when comparing studies in the literature. For most sheep systems where lamb is the major product, BA 2 is arguably the most logical set of assumptions to apply since it fully accounts for lamb meat requirements but allocates breeding animal requirements to both wool and meat. Similar results were obtained using the simplified PMA method which is more easily performed and is a reasonable proxy for the more detailed biophysical methods.

\subsection{Economic allocation}

EA has been the most commonly applied allocation method for sheep systems to date (Brock et al. 2013; Ledgard et al. 2011; Opio et al. 2013; Peters et al. 2010; Williams et al. 2006) and has been argued based on revenue being a price signal that 'drives' production. However, EA will also cause results to vary over time in response to market fluctuations and subsidies or price interventions in addition to changes in environmental impacts, and this could complicate the interpretation of benchmarking results as the knowledge base builds. It is not clear if economic factors should be harmonised by use of the same market values for products from differing time periods or if these economic factors should be an implicit part of an environmental analysis. The common practice of presenting results for only one product in an analysis (i.e. either wool or meat) leaves the possibility of burden shifting between the two products if the economic value changes over time. For benchmarking applications where analysis over time is the objective, such factors may confound results and obscure changes in environmental performance. This could be partly overcome by presenting results for both products and discussing the influence of changed product value on the relative allocation to each product, and by applying fixed economic relationships between products for longitudinal benchmarking studies. However, allocation based on biological processes in the animal are more stable over time and are therefore preferable. Changes in EA factors will impact wool more heavily than meat because the impacts are divided over less product mass and hence this is an issue of greater concern in the wool industry.

\subsection{System expansion}

Regardless of the allocation method chosen, there are inherent weaknesses in an allocation approach. Where benchmarking results are used in a rating system designed to assist product choice decisions (such as the European Commission's Product Environmental Footprint) they are being designed to influence future supply and demand. Arguably, a partial analysis that fails to account for changes in supply and demand of coproducts will not inform decision makers or consumers of the true impact of their decisions. For products that come from sheep, and particularly for wool, the change in supply and demand for meat may have a large effect on overall environmental outcomes. For example, a choice to avoid wool on the basis of perceived high environmental impact may not reduce environmental impacts if declining wool demand resulted in a substitution at the market level between sheep meat and beef. The implications of such changes are best considered through application of SE using consequential modelling. Similar case studies in the dairy sector showed the importance of considering the impacts of change in co-products. Cederberg and 
Stadig (2003) found that higher milk production and fewer dairy cows in the Swedish dairy herd resulted in lower emissions intensity for milk, but no change to total emissions when the induced additional production of beef from suckler cows was taken into account. Considering the similarities with respect to co-production between milk-beef and wool-meat systems, it is likely that similar problems would exist if studies focussed on the emissions intensity of wool without accounting for changes in meat production. Zehetmeier et al. (2012) found that mitigation strategies focussing on one product (milk) without taking into account changes in the co-product system (meat) can result in erroneous conclusions because negative changes in the co-product system have the potential to outweigh positive changes in the main product system. Such problems are best addressed by applying consequential LCA, where system expansion is a preferred approach (Weidema 2000). However, within attributional LCA studies SE may be a suitable comparison method to understand the sensitivity of methodological choices and to improve the interpretation by considering the impact if changes in the coproduct system occurred. Considering the sensitivity of results to methods for handling co-production, the choice to apply attributional or consequential modelling during project inception, based on the goals of the study, is highly important for sheep systems. The disadvantage of system expansion is the added complexity, reliance on sensitive assumptions for coproduct substitution and added difficulty in communicating results.

In this paper, we applied constraints at both production and product levels on the selection of substitution products. Substitution products were selected to (i) replace the product (meat) in the market, and (ii) replace the production system using equivalent natural resources at the production system level. In most cases, dual-purpose sheep can be replaced at the production level by alternative sheep breeds, beef cattle or goats to maintain meat production. Using chicken meat or pork as a substitution product for sheep meat is valid at the product level, but is not possible if the land used for grazing sheep is unsuitable for grain production to feed chickens or pigs. We note also that substitution at the production system level has other implications. For example, cattle graze in a different manner to sheep and this may result in fewer cattle being grazed per hectare of land than would be suggested by the relative feed requirements of each species. For example, research in $\mathrm{NZ}$ on hill country indicates that the equivalent stocking rate for sheep is about $20 \%$ higher than for cattle (Webby 1993), meaning less beef can be produced from the same land area. Similarly, the choice of beef CF value can have a large effect as evidenced by the value for NZ wool changing from -3.4 to $+11.5 \mathrm{~kg} \mathrm{CO}_{2}$-e/ $\mathrm{kg}$ greasy wool by using the $\mathrm{NZ}$ average beef $\mathrm{CF}$ value of $9.2 \mathrm{~kg} \mathrm{CO}_{2}$-e/ $\mathrm{kg} \mathrm{LW}$ (which includes cull dairy cows) rather than the $\mathrm{CF}$ value of $12.2 \mathrm{~kg} \mathrm{CO}_{2}$-e/kg LW relevant specifically to the same class of land as the CS 2 farm. These factors illustrate the importance of careful and detailed analysis when making substitution decisions at the product and production system levels rather than simply using generic alternative meat production systems.

\section{Conclusions}

While meat is the dominant product from global sheep systems, wool is an important co-product that should not be ignored in sheep studies. Decisions regarding the method for handling co-production are more challenging when the implications for both products are given equal consideration, which is particularly important for dual purpose sheep systems. For sheep systems, we provide here a functional BA method based specifically on protein requirements for application in attributional LCA studies. This method generates results that are causally related to production of wool and LW with a higher degree of stability over time than applying an EA method. Specifically, we suggest using the BA 2 method where lambs are a significant product. The PMA method can provide a suitable and simplified BA approach in lieu of more detailed modelling based on DPLS. Application of SE methods showed that results were lower across most impacts compared to the preferred BA approaches, highlighting the sensitivity of studies focused on wool production to methodological choices around co-product handling. Considering the different results achieved when applying SE, careful consideration of attributional and consequential modelling techniques are recommended at the project inception stage for wool studies. We suggest applying SE as a comparison method to highlight sensitivities and to assist in the interpretation of results to avoid erroneous conclusions where a change in supply and demand may occur. Considering that relatively small differences in allocation methodology changed results enough to reorder impacts between case studies, we recommend transparent explanation of allocation methods and reporting of results for both sheep meat and wool products to inform both the food and textile industries.

Acknowledgments The authors acknowledge the support for this project provided by Australian wool growers and the Australian government through Australian Wool Innovation Limited and by the International Wool and Textiles Organisation. We thank Beef + LambNZ for provision of NZ farm survey and related data, and Mark Boyes for assistance with NZ and UK system analyses. The authors wish to thank Dr Pierre Cronje for helpful expert comments on the draft manuscript. We thank Chris Lloyd of EBLEX for providing the UK case farm data and expert comment on UK wool production systems and Dr Barbara Nebel for valuable comments on the manuscript. We also thank Dr Paul Swan, Dr Steve Ranford and Dr Gus Manatsa for helpful discussions on wool production systems and analysis methods.

Open Access This article is distributed under the terms of the Creative Commons Attribution License which permits any use, distribution, and 
reproduction in any medium, provided the original author(s) and the source are credited.

\section{References}

AFRC (1990) Nutritive requirements of ruminant animals: energy, Issue 5 of Report (Agriculture and Food Research Council, Technical Committee on Responses to Nutrients), CAB International

Ayer NW, Tyedmers PH, Pelletier NL, Sonesson U, Scholz A (2007) Coproduct allocation in life cycle assessments of seafood production systems: review of problems and strategies. J Life Cycle Assess 12(7):480-487

Basset-Mens C, Rankin DA, Boyes M, Ledgard S (2007) Life cycle assessment of New Zealand wool carpet-preliminary study. Report by AgResearch, Hamilton, New Zealand

Beef+LambNZ (2013) Compendium of New Zealand farm facts. P13013: 28

Brander M, Wylie C (2011) The use of substitution in attributional life cycle assessment. Greenh Gas Meas Manag 1(3-4):161-166

Brock PM, Graham P, Madden P, Alcock DJ (2013) Greenhouse gas emissions profile for $1 \mathrm{~kg}$ of wool produced in the Yass region, New South Wales: a life cycle assessment approach. Anim Prod Sci 53: 495-508

BSI (2011) PAS 2050:2011 — Specification for the assessment of the life cycle greenhouse gas emissions of goods and services. BSI, London

Cederberg C, Stadig M (2003) System expansion and allocation in life cycle assessment of milk and beef production. Int $\mathrm{J}$ Life Cycle Assess 8:350-356

Cronje PB (2012) Biological partitioning of environmental costs review for wool LCA. Australian Wool Innovation, Sydney

CSIRO (2007) Nutrient requirements of domesticated ruminants. CSIRO, Collingwood

DCCEE (2012) National Inventory Report 2010, Volume 1. Department of Climate Change and Energy Efficiency, Canberra, ACT, Australia

de Vries M, de Boer IJM (2010) Comparing environmental impacts for livestock products: a review of life cycle assessments. Livest Sci 128:1-11

Dolle J-B, Agabriel J, Peyraud J-L, Faverdin P, Manneville V, Raison C et al (2011) Greenhouse gases in cattle breeding: evaluation and mitigation strategies. Prod Anim 24(5):415-431

Eady S, Carre A, Grant T (2012) Life cycle assessment modelling of complex agricultural systems with multiple food and fibre co-products. J Cleaner Prod 28:143-149

EBLEX (2012) Down to earth: The beef and sheep roadmapphase three. EBLEX, Agriculture \& Horticulture Development Board, England

EBLEX (2013) The outlook and opportunities for the English sheep industry: 2010 and beyond. EBLEX, Agriculture \& Horticulture Development Board, England

Edwards-Jones G, Plassmann K, Harris IM (2009) Carbon footprinting of lamb and beef production systems: insights from an empirical analysis of farms in Wales, UK. J Agric Sci 147:707-719

FAOSTAT (2014) Food and Agriculture Organisation of the United Nations: Statistics. FAO. http://faostat.fao.org/site/613/default. aspx\#ancor. Accessed January 312014

Finnveden G, Hauschild MZ, Ekvall T, Guinée J, Heijungs R, Hellweg S, Koehler A, Pennington D, Suh S, (2009) Recent developments in life cycle assessment. J Environ Manag 91:1-21

Flysjö A, Cederberg C, Henriksson M, Ledgard S (2011) How does coproduct handling affect the carbon footprint of milk? Case study of milk production in New Zealand and Sweden. J Life Cycle Assess $16: 420-430$
Freer M, Moore AD, Donnelly JR (1997) GRAZPLAN: decision support systems for Australian grazing enterprises-II. The animal biology model for feed intake, production and reproduction and the GrazFeed DSS. Agric Syst 54:77-126

Frischknecht R, Jungbluth N, Althaus H, Bauer C, Doka G, Dones R, Hischier R, Hellweg S, Humbert S, Köllner T (2007) Implementation of life cycle impact assessment methods vol ecoinvent report No. 3, v2.1. Swiss Centre for Life Cycle Inventories, Dübendorf, Switzerland

Gac A, Ledgard S, Lorinquer E, Boyes M, Le Gall A (2012) Carbon footprint of sheep farms in France and New Zealand: comparison of results and methodology analysis. In: Corson MS, van der Werf HMG (eds) 8th International Conference on Life Cycle Assessment in the Agri-Food Sector (LCA Food 2012), Saint Malo, France. INRA, Rennes

Gerber P, Steinfeld H, Henderson B, Mottet A, Opio C, Dijkman J, Falcucci A, Tempio G (2013) Tackling climate change through livestock: a global assessment of emissions and mitigation opportunities. Food and Agriculture Organization of the United Nations (FAO)

Howden SM, Munro RK (1994) Methane from Australian livestock; implications for the greenhouse effect. Resour Sci Interface 4:5-9

Howden SM, White DH, McKeon GM, Scanlan JC, Carter JO (1994) Methods for exploring management options to reduce greenhouse gas emissions from tropical grazing systems. Clim Chang 27:49-70

IDF (2010) A common carbon footprint approach for dairy: the IDF guide to standard lifecycle assessment methodology for the dairy sector Bulletin of the International Dairy Federation 445

IPCC (2006) Emissions from livestock and manure management. In: Eggleston S, Buendia L, Miwa K, Ngara T, Tanabe K (eds) IPCC guidelines for national greenhouse gas inventories, vol 4: agriculture, forestry and other land use. Institute for Global Environmental Strategies, IGES, Japan

ISO (2006) ISO 14044: environmental management-life cycle assessment-requirements and guidelines. International Organisation for Standardisation, Geneva

Koellner T, de Baan L, Beck T, Brandão M, Civit B, Margni M, Canals M i, Saad R, Maia de Souza D, Müller-Wenk R (2013) UNEP-SETAC guideline on global land use impact assessment on biodiversity and ecosystem services in LCA. Int J Life Cycle Assess 18(6):1188-1202

LEAP (2014) Greenhouse gas emissions and fossil energy demand from small ruminant supply chains: guidelines for quantification. United Nations Food and Agriculture Organisation, Rome

Ledgard SF, Lieffering M, Coup D, O'Brien B (2011) Carbon footprinting of New Zealand lamb from the perspective of an exporting nation. Animal Front 1:27-32

Lieffering M, Ledgard S, Boyes M, Kemp R (2010) Beef greenhouse gas footprint: Final report Hamilton: AgResearch 95p

MfE (2010) New Zealand's Greenhouse Gas Inventory 1990-2006: an overview. NZ Ministry of the Environment, Wellington

MLA (2003) Live assessment yard book: sheep and lamb. Meat \& Livestock Australia Limited

Nguyen TTH, van der Werf HMG, Eugène M, Veysset P, Devun J, Chesneau G, Doreau M (2012) Effects of type of ration and allocation methods on the environmental impacts of beef-production systems. Livest Sci 145:239-251

Opio C, Gerber P, Mottet A, Falcucci A, Tempio G, MacLeod M, Vellinga T, Henderson B, Steinfeld H (2013) Greenhouse gas emissions from ruminant supply chains - a global life cycle assessment. Food and Agriculture Organization of the United Nations, Rome

Peters GM, Rowley HV, Wiedemann SG, Tucker RW, Short MD, Schulz MS (2010) Red meat production in Australia: life cycle assessment and comparison with overseas studies. Environ Sci Technol 44: $1327-1332$ 
Reap J, Roman F, Duncan S, Bras B (2008) A survey of unresolved problems in life cycle assessment. J Life Cycle Assess 13(5):374 388

Ripoll-Bosch R, de Boer IJM, Bernués A, Vellinga TV (2013) Accounting for multi-functionality of sheep farming in the carbon footprint of lamb: a comparison of three contrasting Mediterranean systems. Agric Syst 116:60-68

Sanson D, West T, Tatman W, Riley M, Judkins M, Moss G (1993) Relationship of body composition of mature ewes with condition score and body weight. J Anim Sci 71:1112-1116

Solomon S, Qin D, Manning M, Chen Z, Marquis M, Averyt K, Tignor M, Miller H (2007) The physical science basis. Contribution of working group I to the fourth assessment report of the intergovernmental panel on climate change, pp 235-337

Steinfeld H, Gerber P, Wassenaar T, Castel V, de Haan C (2006) Livestock's long shadow: environmental issues and options. Food and Agriculture Organisation of the United Nations, Rome

Thomas SM, Ledgard SF, Francis GS (2005) Improving estimates of nitrate leaching for quantifying New Zealand's indirect nitrous oxide emissions. Nutr Cycl Agroecosyst 73:213-226

Thomassen M, Dolman M, Van Calker K, De Boer I (2009) Relating life cycle assessment indicators to gross value added for Dutch dairy farms. Ecol Econ 68:2278-2284

van der Werf HM, Kanyarushoki C, Corson MS (2009) An operational method for the evaluation of resource use and environmental impacts of dairy farms by life cycle assessment. J Environ Manag 90:3643-3652

Webby R (1993) Improving the balance of sheep and beef cattle livestock systems. In: Proceedings of the New Zealand Grassland Association, 1993. New Zealand Grassland Association, pp 73-76

Weidema B (2000) Avoiding co-product allocation in life-cycle assessment. J Ind Ecol 4:11-33

Wiedemann S, McGahan E, Murphy C, Yan M-J, (2015a) Resource use and environmental impacts from beef production in eastern Australia investigated using life cycle assessment. J Anim Prod Sci. In press

Wiedemann SG, Yan M-J, Murphy CM, (2015b) Resource use and environmental impacts from Australian export lamb production: a life cycle assessment. J Anim Prod Sci. In press

Williams AG, Audsley E, Sandars DL (2006) Determining the environmental burdens and resource use in the production of agricultural and horticultural commodities vol Main Report. National Resource Management Institute, Cranfield University and Defra Bedford

Zehetmeier M, Gandorfer M, Heibenhuber A, de Boer IJM Modelling GHG emissions of dairy cow production systems differing in milk yield and breed - the impact of uncertainty. In: 8th International Conference on Life Cycle Assessment in the Agri-Food Sector (LCA Food 2012), Saint Malo, France. INRA, Rennes, France, 14 October 2012

Zygoyiannis D (2006) Sheep production in the world and in Greece. Small Rumin Res 62:143-147 